\title{
Study on the Technology of Roadway Mining with Paste-like Backfill under Highway and Its Application
}

\author{
Yu Dong, 2, a, Junwei Shi ${ }^{1, b}$, Zhangliang Chen ${ }^{1, \mathrm{c}}$, Gang Liu ${ }^{1, \mathrm{~d}}$ and Lifeng $\mathrm{Li}^{1, \mathrm{e}}$ \\ ${ }^{1}$ School of Management Science and Engineering, Shandong Technology and Business University, \\ Yantai, 264005, China \\ ${ }^{2}$ School of Resources and Safety Engineering, China University of Mining \& Technology (Beijing), \\ Beijing, 100083, China \\ adongyu1987@126.com, ${ }^{\mathrm{b}} 542670686 @ q q . c o m,{ }^{\mathrm{c}}$ chenzhl_yt@126.com, diugang7912@163.com, \\ 'lifeng_309@126.com
}

Keywords: Highway, Coal Mining, Roadway Backfill, Paste-like Backfill.

Abstract. Based on the research of paste-like backfill technology in roadway mining under highway of Tang'an Coal Mine, the mining scheme was elaborated, the system and technology of roadway mining with paste-like backfill were introduced, the technical effects and economic benefits were analyzed. The results showed that the surface maximum deformations within the scope of the highway are less than the degree of protection I allows. On the premise of ensuring the safe operation of highway, 4.4095 million tons of coal resources can be liberated by the application of roadway mining with paste-like backfill technology, with having great economic and social benefits.

\section{Introduction}

Highway, the artery of national economy, with large traffic flow and high speed, is sensitive to mining subsidence damage [1]. There will be a significant economic losses and social impact, if the normal traffic is affected by roadbed subsidence. Therefore, the mining regulation of coal pillars under the building, water, railway and main shaft in our country stipulates that mining under highway belongs to the degree of protection I [2]. The new highway through Tang'an Coal Mine, covers a large amount of coal resources, brings mining problems and seriously affects the mine's original production plan. In order to improve the coal recovery rate and liberate the coal resources under highway, research of mining technology under highway is imperative.

\section{Project Profile}

GaoQin highway passes through the southern part of Tang'an Coal Mine from west to east, occupying a large number of high quality coal resources. Only the coal of no.3 coal seam (6 meters on average thickness), occupied under highway in the third panel is more than 5 million tons. Along with the coal of no. 3 coal seam in other panels and no.9, no. 15 coal seam under the highway, the coal resources amount to tens of million tons. Among them, there is a 1500 meters highway passing through the earth's surface of the third panel on the left, as shown in Fig. 1. The highway's roadbed is about 30 meters width, with ground elevation of 1140 meters, and the vertical distance from highway to the no. 3 coal seam is about 430 meters.

\section{Scheme of Coal Mining under Highway}

There are some typical methods of coal mining under buildings, railway and water, such as strip mining method and backfill mining method. By contrast, coal mining with backfill mined-out area could not only control the mining subsidence, but also improve the coal resources recovery rate. It is a most efficient mining method of mining under buildings, railway and water [3].

In view of the current backfill technological level, fully mechanized caving working face with backfill mined-out area is feasible. In addition, for Tang'an Coal Mine, mining coal pillars with backfill 
under highway belongs to partial backfill method, specializing the backfill supports of fully mechanized coal mining in backfill the long wall working face could increase the investment in coal mining equipments and complicate the production management. Through overall consideration, for partial backfill mining, roadway mining with backfill method has the advantage of less investment and flexible process. Therefore, roadway mining with paste-like backfill method is more suitable for coal mining under highway.

According to Tang'an Coal Mine production plan, no.3308 working face was intended to be the first mining face in the left of the third panel. Taking the backfill efficiency and surface subsidence into consideration, backfill mining the highway coal pillar area of no.3308 working face first (I), then caving mining the south(II) and north (III) side area of highway coal pillar. It is as shown in Fig. 1.

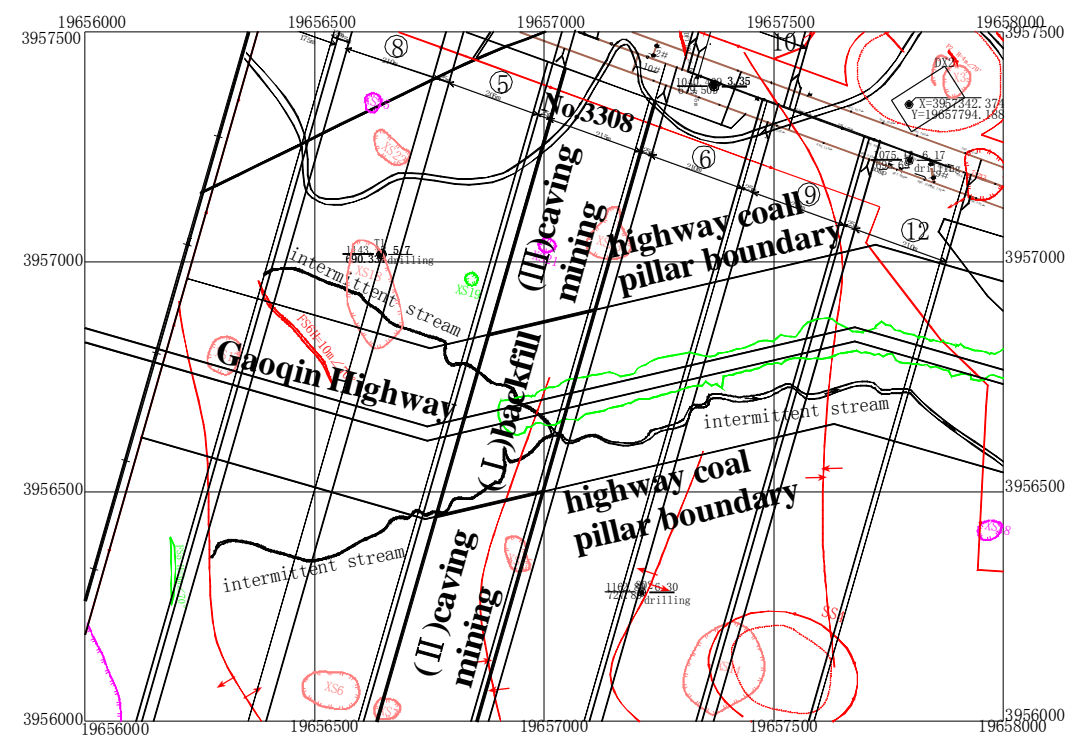

Fig. 1 Highway location of surface and underground

\section{Technology of Roadway Mining with Paste-like Backfill}

Brief Introduction of Roadway Backfill Technology. For the past few years, roadway backfill technology has been got more and more application and development in our country's coal mine. The main technological process is: using the development machine to excavate roadway in proper order in the planning area, supporting is close behind, then after excavating, the roadway is filled by backfill materials. This method could not only reduce the backfill cost, improve the backfill efficiency, but also reduce the influence between backfill and mining [4].

According to the geological and production data of Tang'an Coal Mine, based on the theory analysis and other coal mine backfill construction experience, the reasonable width of coal (backfill body) pillar between two adjacent roadway was determined to 15 meters.

Taking no.3308 working face for example, the excavating and backfill sequence of backfill-roadway is as shown in Fig. 2. The backfill area along the working face strike was 360 meters, which was divided into 69 backfill-roadways with four circulations. And a 10 meters coal pillar was left between the fist backfill-roadway and open-off cut.

System Technology of Paste-like Backfill. Coal mining with paste-like backfill is a mining method that it takes advantage of the new technology of paste-like backfill to fill close behind coal mining working face, in order to control the deformation and subsidence of overlying rock strata at the extreme [5]. Composition of backfill materials: as the concentration of the paste-like backfill is $78 \%$, the corresponding ratio of slurry includes $5 \%$ cementing material, 53\% coal gangue, $20 \%$ fly ash and $22 \%$ water. 


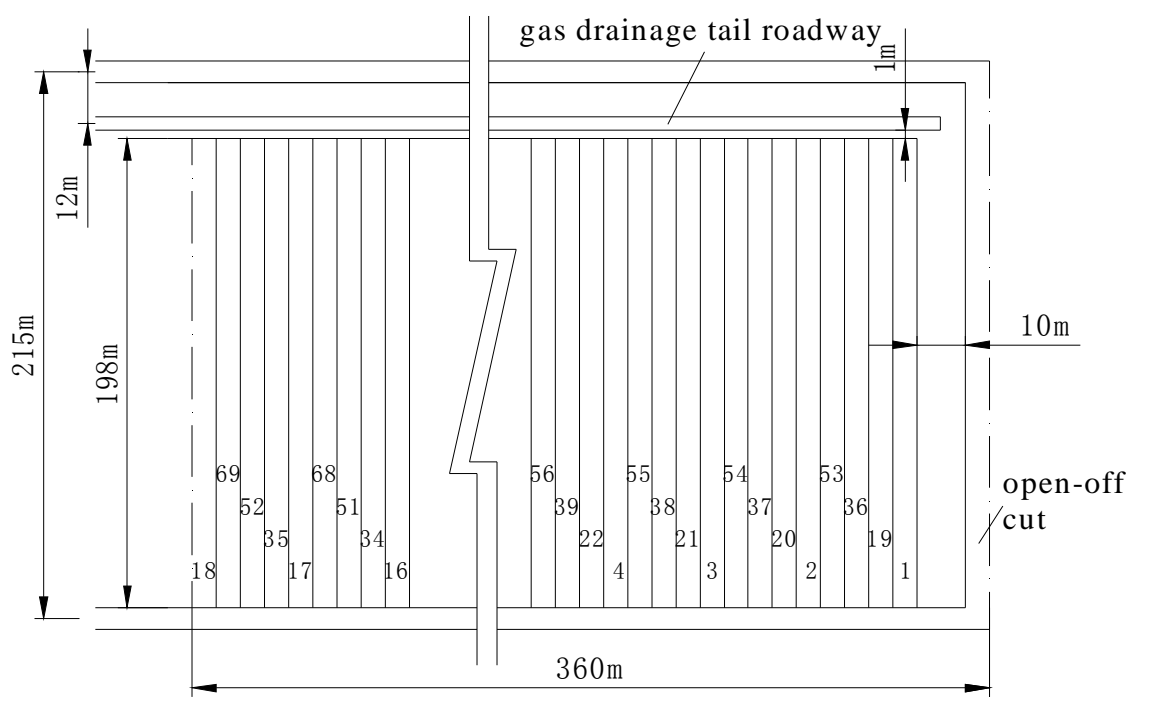

Fig. 2 Backfill-roadway driving and backfill sequence

Process of backfill: at first, to process the fragmentized coal gangue, in the next place, mixing the coal gangue, fly ash, special cementing material and water in proportion to make into paste-like slurry, then, through backfill pump, the paste-like backfill slurry will be transported to the underground working face to backfill confined space of mined-out area which was formed by hydraulic backfill support with secondary isolation measures.

The entire backfill process flow is as shown in Fig. 3.

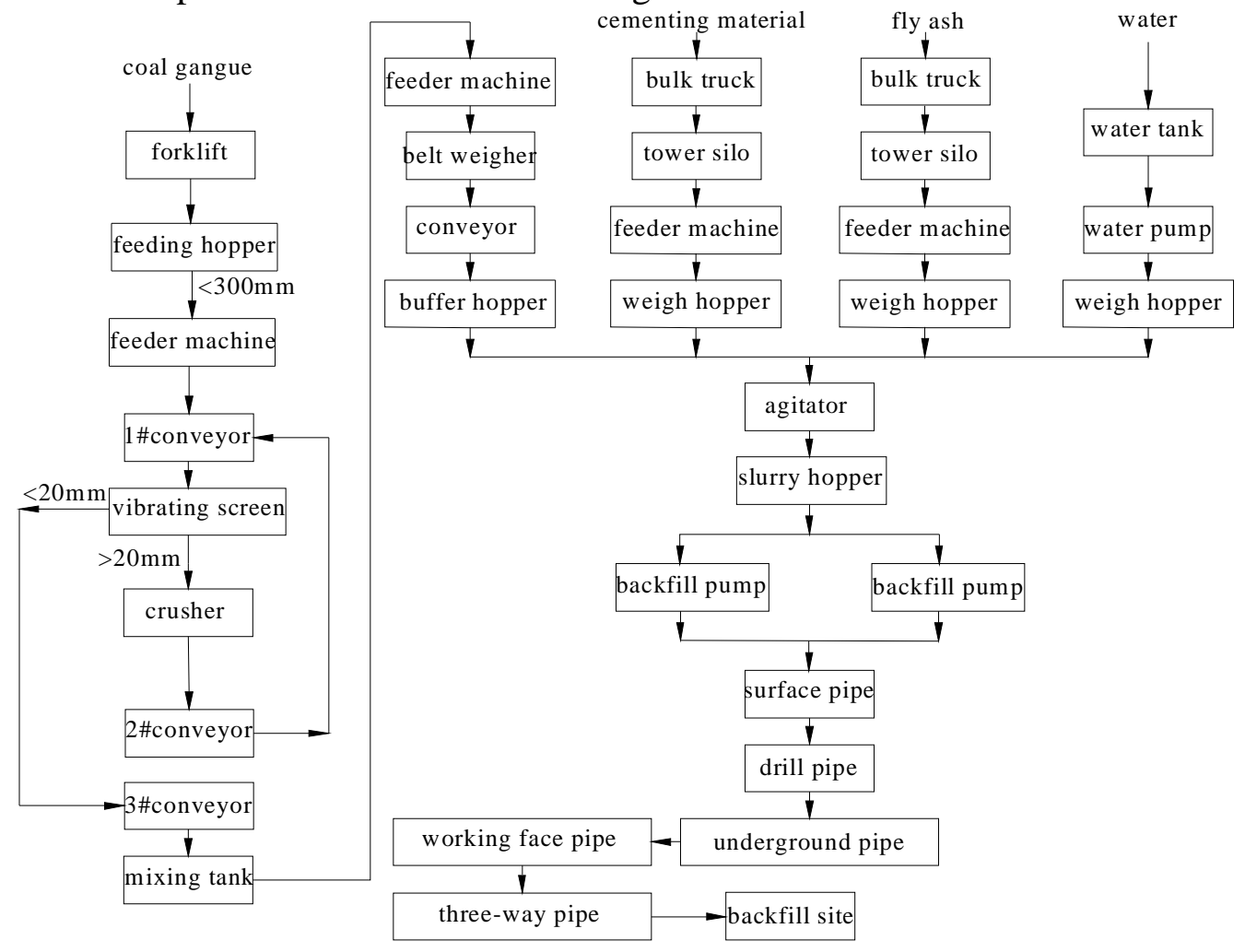

Fig. 3 Process of paste-like backfill technology and system

Production System of Working Face. The haulage roadway, return airway, open-off cut and backfill pipeline which was setting up in gas drainage tail roadway constitute the transportation, ventilation, backfill and other production system. The production system is as shown in Fig. 4.

Coal transportation system: backfill-roadway excavating face $\rightarrow$ backfill-roadway $\rightarrow$ haulage roadway $\rightarrow$ main belt haulage roadway in the third panel.

Ventilation system: main belt haulage roadway in the third panel $\rightarrow$ haulage roadway $\rightarrow$ backfill-roadway $\rightarrow$ open-off cut $\rightarrow$ returned airway $\rightarrow$ special return airway in the third panel. 
Backfill system: special return airway in the third panel $\rightarrow$ gas drainage tail roadway $\rightarrow$ backfill-roadway

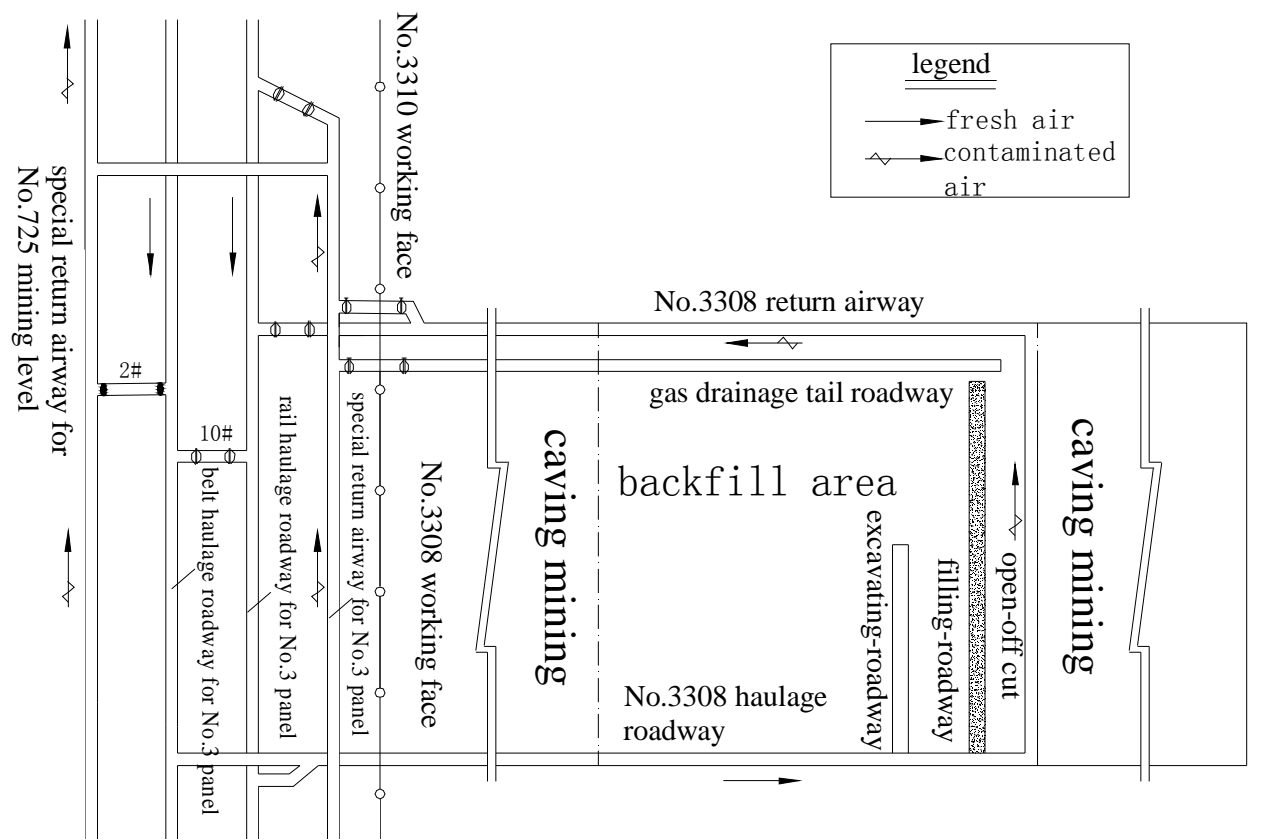

Fig. 4 Production system of paste-like backfill in roadway mining

Backfill Process of Roadway. The upper slice was excavated till one meter apart from gas drainage tail roadway with small triangle coal pillar for roadway protection was setting up in lower slice. After the two slices were mined out, a baffle plate was setting up at the end region of backfill roadway close to haulage roadway, and a drill was made from gas drainage tail roadway to backfill roadway for the slurry conveying pipe placement. Later on, the roadway was being filled. The roadway backfill process is as shown in Fig. 5.

\section{Technical and Economic Analysis}

By the calculation of surface movement and deformation, highway pillar backfill mining and non pillar area caving mining in the third panel left slightly influence the highway. The surface maximum deformations within the scope of the highway are less than the allowable deformation about the degree of protection I, which conforms the regulation and requirement about the mining regulation of coal pillars under the building, railway, water and main shaft.

Therefore, it is safe and feasible that caving mining the non pillar area in the third panel left after backfill mining the highway pillar.

No.3 coal seam could be mined about 4,409,500 tons by the method of backfill in the mining area under the highway. The profit is 200 per ton using the method of caving mining and the cost of backfill is $42.5 \mathrm{RMB}$ per ton, so the profit of backfill is $157.5 \mathrm{RMB}$ per ton, and the total profit will be 694,496,000 RMB.

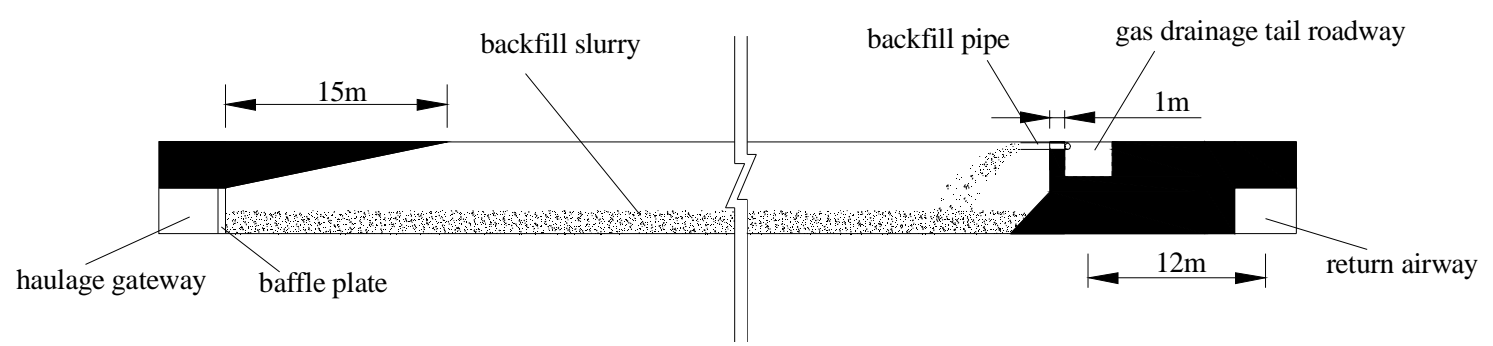

Fig. 5 Process of paste-like backfill in roadway 


\section{Conclusions}

Results from this study showed that roadway mining with paste-like backfill having flexible working face layout, high coal recovery rate, low cost of backfill, slight mutual influence between backfill and coal mining and high backfill efficiency is more suitable for partial backfill. The surface maximum deformations are less than the allowable deformation about the degree of production I by roadway mining with paste-like backfill. The surface subsidence is controlled well, and a new approach for solution to the coal mining under the highway is provided. On the condition that it can ensure the safety of highway, 4,409,500 tons of coal resources will be liberated by the technology of paste-like backfill . The technology can also raise the coal recovery rate and extend the mine life with greater economic and social benefits. This study demonstrated that the aggregate of paste-like backfill slurry made up of solid waste such as coal gangue, fly ash could open up a new way to optimizing resources utilization, offer conditions to improve the mining area environment and to create the green mine.

\section{Acknowledgements}

This work was financially supported by the Youth Foundation of Shandong Technology and Business University (2015QN014) and PhD Research Startup Foundation of Shandong Technology and Business University (BS201522).

\section{References}

[1] CHEN Xinming, LI Xiaoshuang, GUO Wenbing. Energy Technology and Management 2007,(05):142-144. In Chinese.

[2] State Bureau of Coal Industry enacted. Mining regulations under buildings, water, railway and coal pillars. [S]. Beijing: China Coal Industry Publishing House,2000:10-12. In Chinese.

[3] HUANG Yucheng, SUN Henghu, SHI Zhaobing, et al. Coal Science and Technology 2003,(10):51-53. In Chinese.

[4] HUANG Yucheng, WU Yang, CHANG Jun. Coal Science and Technology 2014, 42(1):37-39, 54. In Chinese.

[5] HUANG Yu-cheng, FENG Rui-min, WANG Hong-pan, et al. The Coal Mining Mode of Paste-like Fill and Its Application Prospects [J]. Advances in Civil Engineering, 2011(4): 3744-3748. 